\title{
Peran Etnomatematika di Sekolah dalam Upaya Peningkatan Stigma Positif Pelajar Terhadap Pembelajaran Matematika
}

\author{
Elvira Mentari Awaliyah \\ ${ }^{1}$ Mahasiswa Universitas Majalengka (Fakultas Hukum ) \\ Email : elviramentari25@gmail.com
}

\begin{abstract}
Abstrak - Pada skema pembelajaran matematika saat ini, pembelajaran matematika cenderung lebih fokus pada pencapaian target materi atau isi materi yang digunakan dalam buku ajar, berdasar pada soalsoal Ujian Nasional. Hal ini berdampak pada kurangnya perhatian siswa terhadap pemecahan masalah matematika dasar, yang seharusnya menjadi sesuatu yang dapat membuat siswa menjadi tertarik untuk melatih daya kreativitas dan terfokus pada pemecahan masalah.Penelitian ini bertujuan untuk (1) menelaah sikap siswa terhadap pembelajaran matematika yang diterapkan di sekolah pada kurikulum yang berlaku saat ini. (2) Menelaah kesulitan siswa secara umum dalam pembelajaran matematika hingga saat ini. (3) Menelaah cara untuk membangun kembali daya minat siswa dalam mempelajari matematika pada pembelajaran formal. (4) Menelaah efektifitas pembelajaran matematika apabila guru meggunakan skema pembelajaran etnomatematika atau matematika dengan menerapkan unsur budaya. (5) Menelaah unsur budaya seperti apa yang cocok agar dapat dipergunakan secara umum dalam lingkup pembelajaran di sekolah. Teknik pengumpulan bahan analisis data, penulis menggunakan metode survei. Survei digunakan dalam pengumpulan data dan tidak dibuat perlakuan (treatment) atau pengkondisian terhadap variabel yang diteliti, namun hanya mengungkap fakta berdasarkan gejala sosial yang ada pada siswa, tenaga pendidik maupun responden lainnya. Berdasarkan analisis data, ditemukan beberapa macam skema pembelajaran berbasis budaya (etnomatematika) yang cocok untuk dimasukkan kedalam pembelajaran matematika. Untuk karya tulis ini, penulis menggunakan unsur lagu dan kesenian sebagai media pembelajaran matematika.
\end{abstract}

Kata kunci: Etnomatematika, Stigma Positif, Pembelajaran Matematika 


\section{PENDAHULUAN}

Pendidikan memiliki peran yang sangat krusial dalam meningkatkan sumber daya manusia di masa yang akan datang. Selain untuk menunjang kehidupan, pendidikan juga menjadi tolok ukur berkembangnya sebuah bangsa. Apabila pendidikannya baik, maka potensi sumber daya manusia di negara tersebut cenderung lebih baik. Pendidikan di Indonesia pada umumnya dibagi menjadi 2 (dua) bagian, diantaranya yaitu pendidikan formal dan pendidikan nonformal. Pendidikan formal dapat diartikan sebagai pendidikan yang dipelajari dalam lingkup lembaga pendidikan baik bersifat umum maupun bersifat khusus, seperti sekolah, bimbel (bimbingan belajar), atau sejenisnya. Sedangkan, pendidikan nonformal merupakan pendidikan yang diperoleh seseorang tanpa perantara lembaga pendidikan, melainkan terbentuk atau berkembang dengan sendirinya.

Pendidikan formal lebih cenderung kepada pendidikan yang membentuk siswanya untuk melakukan sesuatu sesuai dengan apa yang diinginkan lembaga pendidikan tertentu. Misalnya, ketika suatu lembaga pendidikan membuka sebuah institusi yang khusus bergerak dibidang Kedokteran. Maka, seseorang yang menempuh pendidikan di institusi pendidikan tersebut akan dibentuk menjadi seorang dokter atau menjalani pekerjaan yang khususnya bergerak pada bidang kedokteran. Lain halnya dengan pendidikan nonformal, untuk pendidikan nonformal sendiri, keterampilan seseorang lebih cenderung tidak dengan sengaja dibentuk, melainkan terbentuk atau berkembang dengan sendirinya. Sebab, untuk pendidikan nonformal lazimnya didapatkan melalui kebiasaan atau tingkah laku masyarakat sekitar, baik didapat dari teman, tetangga, lingkungan dan yang terpenting keluarga. Hal ini, menjadikan pendidikan nonformal sebagai penentu seseorang dalam masyarakat. Sebab, fokus utama dari pendidikan nonformal ini dapat menjadi penentu pola pikir, perilaku, tingkah laku, watak seseorang yang sebenarnya.

Pendidikan formal lebih condong dikenal sebagai pendidikan terstruktur atau tersusun. Mata pelajaran misalnya. Mata pelajaran merupakan pelajaran yang harus diajarkan (dipelajari) untuk sekolah dasar atau lanjutan (KBBI, 2016). Salah satu contoh umum yaitu mempelajari mata pelajaran matematika. Mata pelajaran matematika merupakan mata pelajaran mendasar pada jenjang pendidikan sekolah dasar dan menengah. Mempelajari matematika sama dengan mempelajari sebagian dari kehidupan, sebab, pengaplikasian matematika saling melekat satu sama lain dalam kehidupan sehari-hari. Selain itu, mata pelajaran matematika merupakan mata pelajaran yang juga mampu mengembangkan kesadaran tentang nilai-nilai yang esensial, mendasar atau hakiki. Sesuai dengan pendapat Mulyana (2004: 180) mengatakan bahwa matematika selain dapat memperluas cakrawala berpikir peserta didik, juga dapat mengembangkan kesadaran tentang nilai-nilai yang secara esensial terdapat didalamnya (Mulyana, 2004) .

Salah satu kenyataan yang hadir pada skema pembelajaran matematika saat ini yaitu pembelajaran matematika cenderung lebih terpatok pada pencapaian target materi atau isi materi yang digunakan dalam buku ajar, dengan berdasar kepada soal-soal Ujian Nasional. Hal ini justru berdampak pada kurangnya perhatian siswa terhadap pemecahan masalah matematika mendasar, yang seharusnya menjadi bahan pemikat 
siswa untuk melatih daya kreativitas dan terfokus pada pemecahan masalah. Selain itu, untuk pembelajaran dengan skema pembelajaran tersebut di atas, aktivitas siswa cenderung menjadi lebih terbatasi, kemudian siswa cenderung menjadi cepat jenuh, dan pada akhirnya membangun stigma yang kurang baik mengenai pembelajaran matematika. Biasanya ini dimulai sejak jenjang sekolah dasar atau menengah dalam sekolah formal.

Untuk membangun kembali daya minat siswa terhadap pembelajaran matematika, tentu harus selaras dengan pembangunan stigma positif siswa terlebih dahulu. Sebab, apabila pemikiran yang dimiliki siswa tersebut kurang baik, maka perlakuannya terhadap pembelajaran tersebut akan cenderung kurang baik. Salah satu cara agar siswa menyukai pembelajaran matematika yakni dengan mengubah, menambahkan atau memperbaiki skema pembelajaran itu sendiri. Misalnya, dengan pembentukan skema baru yang dikemas semenarik mungkin oleh guru agar siswa lebih tertarik mempelajari pendidikan matematika dalam bentuk formal. Atau untuk opsi lain, guru memasukkan unsur nonformal dalam skema pembelajaran. Unsur nonformal disini, misalnya, guru menempatkan peran Etnomatematika atau penerapan matematika yang memasukkan unsur dari budaya tertentu atau dalam hal ini budaya sekitar di sekolah

\section{METODE PENELITIAN}

Metode yang dipergunakan dalam karya tulis ini adalah metode survei. Survei digunakan dalam pengumpulan data dan tidak dibuat perlakuan (treatment) atau pengkondisian terhadap variabel yang diteliti, namun hanya mengungkap fakta berdasarkan gejala sosial yang ada pada siswa, tenaga pendidik maupun responden lainnya. Survei sampel yang dilakukan dalam karya tulis ilmiah ini merupakan survei sampel yang tidak nyata (Intangibles), yaitu suatu keadaan dimana survei ini dilakukan berdasarkan informasi pada populasi yang besar, dengan melibatkan variabel yang tidak dapat diamati secara langsung. Maka, data konkret dari karya tulis ini dikenal dengan metode survei sampel yang tidak nyata ( $A$ Sample Survey of Intangibles).

Berdasarkan latar belakang diatas maka penelitian ini bertujuan untuk 1) menelaah sikap siswa terhadap pembelajaran matematika yang diterapkan di sekolah pada kurikulum yang berlaku saat ini. 2) Menelaah kesulitan siswa secara umum dalam pembelajaran matematika hingga saat ini. 3) Menelaah cara untuk membangun kembali daya minat siswa dalam mempelajari matematika pada pembelajaran formal. 4). Menelaah efektifitas pembelajaran matematika apabila guru meggunakan skema pembelajaran etnomatematika atau matematika dengan menerapkan unsur budaya. 5). Menelaah unsur budaya seperti apa yang cocok agar dapat dipergunakan secara umum dalam lingkup pembelajaran di sekolah.

\section{HASIL DAN PEMBAHASAN}

A. Etnomatematika Sebagai Salah Satu Langkah Konkret Untuk Membangun Kembali Stigma Positif Siswa Terhadap Pembelajaran Matematika

Pendekatan pembelajaran berbasis Etnomatematika atau budaya, sebenarnya sudah lama diperkenalkan di Indonesia. Namun, untuk pengaplikasiaannya belum sepenuhnya dipergunakan. Pembelajaran dalam skema ini, lebih mengutamakan penyatuan antara budaya dan 
matematika menjadi satu kesatuan yang utuh, menjadikan budaya sebagai perantara pembelajaran matematika atau sebaliknya. Selaras dengan apa yang dikatakan oleh Sardjiyo Paulina Pannen bahwa pembelajaran berbasis budaya merupakan suatu model pendekatan pembelajaran yang lebih mengutamakan aktivitas siswa dengan berbagai macam latar belakang budaya yang dimiliki, diintegrasikan dalam proses pembelajaran bidang studi tertentu, dan dalam penilaian hasil belajar dapat menggunakan beragam perwujudan penilaian. Pembelajaran berbasis budaya dapat dibedakan menjadi tiga macam, yaitu belajar tentang budaya, belajar dengan budaya, dan belajar melalui budaya. Pembelajaran berbasis budaya merupakan strategi penciptaan lingkungan belajar dan perancangan pengalaman belajar yang mengintegrasikan budaya sebagai bagian dari proses pembelajaran. Pembelajaran berbasis budaya dilandaskan pada pengakuan terhadap budaya sebagai bagian yang fundamental (mendasar dan penting) bagi pendidikan sebagai ekspresi dan komunikasi suatu gagasan dan perkembangan pengetahuan (Supriadi, 2010).

$\begin{array}{ccc}\text { Gagasan } & \begin{array}{c}\text { Matematika } \\ \text { perspektif }\end{array} & \text { dalam } \\ \text { budaya } & \text { atau }\end{array}$

Etnomatematika memiliki peluang lebih dalam memperkaya pengembangan pembelajaran matematika yang telah ada. Oleh sebab itu, jika perkembangan Etnomatematika lebih banyak dikaji kembali, maka bukan tidak mungkin matematika yang diajarkan di lembaga pendidikan formal, khususnya di sekolah atau lembaga sejenis, dapat menjadi pelajaran yang menyenangkan untuk dipelajari. Matematika merupakan suatu bentuk budaya. Matematika sebagai bentuk budaya, sesungguhnya telah terintegrasi pada seluruh aspek kehidupan masyarakat dimanapun berada (Bishop, 1994b). Pada hakekatnya matematika merupakan teknologi simbolis yang tumbuh pada ketrampilan atau aktivitas lingkungan yang bersifat budaya (Pixten, 1994). Dengan demikian matematika seseorang dipengaruhi oleh latar budayanya, karena yang mereka lakukan berdasarkan apa yang mereka lihat dan rasakan. Budaya akan mempengaruhi perilaku individu dan mempunyai peran yang besar pada perkembangan pemahaman individual, termasuk pembelajaran matematika (Bishop, 1991).

\section{B. Keefektifan Etnomatematika Yang Dapat Dikembangkan Dalam Pembelajaran Ditinjau Dari Analisis Data \\ Dari beberapa pertanyaan yang} diajukan langsung oleh penulis kepada responden pada tanggal 15 April 2019 melalui laman isian Google Formulir (Google Form), terdapat 30 (tiga puluh) penjawab yang diantaranya menjawab opsi Ya/Tidak/Mungkin dan menjawab berdasarkan hasil penalaran masing-masing yang diantaranya dapat diperoleh data sebagai berikut:

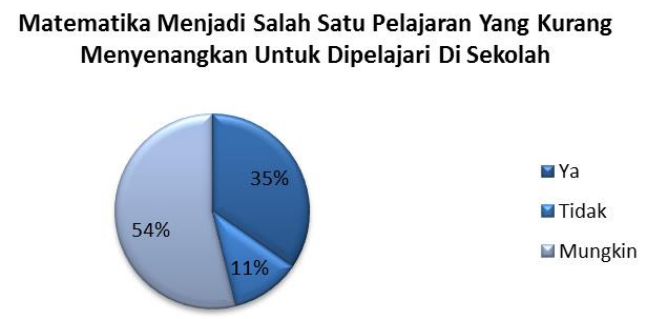

Dari diagram lingkaran di atas, dapat disimpulkan bahwa rata-rata penjawab yang didominasi oleh siswa yang dahulunya pernah atau sedang menempuh pendidikan di sekolah dasar dan menengah, mahasiswa aktif 
perguruan tinggi dan beberapa penjawab lain berasal dari masyarakat usia 22-27 tahun menyatakan bahwa, mata pelajaran matematika lebih termasuk dalam mata pelajaran yang kurang menyenangkan di sekolah. Hal ini selaras dengan pernyataan yang diajukan penjawab pada isian berikutnya yakni:

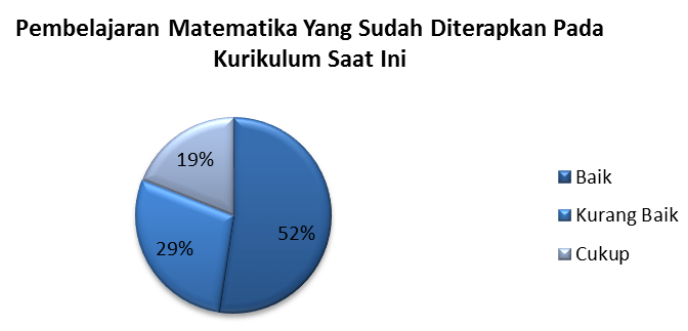

Dari pernyataan di atas dapat disimpulkan bahwa, kurikulum dalam pembelajaran matemarika yang sedang berlaku saat ini cenderung baik atau cukup. Namun masih dinilai membosankan atau kurang menyenangkan. Menurut salah satu penjawab, ia memaparkan bahwa Pendidikan matematika yang diberikan di sekolah sejauh ini lebih baik dari sebelumnya, bahkan lebih banyak variasi yang diajarkan. Namun, metode pembelajarannya masih kurang memacu siswa untuk menyukai matematika. Sebab, metode pembelajaran yang diberikan oleh guru cenderung monoton bahkan terlalu membosankan. Hanya sebatas guru memberi contoh soal dari buku ajar, kemudian dijelaskan dan memberikan tugas kepada siswa. Penjawab berpendapat bahwa akan lebih baik apabila metode pendidikan matematika dikemas lebih menyenangkan. Karena matematika sesungguhnya tidak membosankan melainkan menyenangkan seperti sedang mengerjakan sebuah tantangan

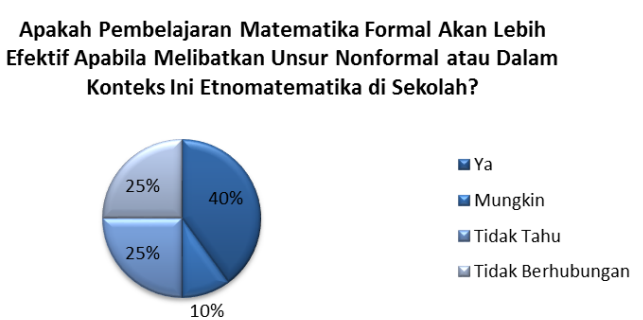

Pada pernyataan selanjutnya, penulis memberikan pertanyaan terkait pembelajaran matematika formal yang melibatkan unsur nonformal atau dalam konteks ini mengambil unsur budaya (Etnomatematika). Kemudian penulis menelaah pandangan responden terhadap hal tersebut, mengacu pada pembahasan sebelumnya mengenai pembelajaran matematika yang dinilai kurang menarik, monoton bahkan lebih terkesan membosankan. Dan unsur budaya apa yang cocok disisipkan dalam pembelajaran matematika pada umumnya.

Sebagian responden menjawab tidak tahu/tidak paham dan tidak berhubungan, namun sebagian besar menjawab ya dan mungkin. Salah satu penjawab menjelaskan bahwa untuk saat ini, hal tersebut patut dipertimbangkan lebih lanjut untuk diuji coba. Sebab, dalam skema pembelajaran matematika berbasis budaya sendiri dapat memungkinkan siswa untuk lebih mengeksplorasi daya kreativitas serta aktivitas siswa itu sendiri melalui pengaplikasian dari matematika melalui unsur budaya. Namun, untuk lebih lanjutnya, penjawab belum dapat sepenuhnya menyimpulkan apakah skema pembelajaran tersebut dapat efektif atau tidak.

Salah satu responden lain memaparkan temuannya bahwa keefektifan pembelajaran matematika dapat dimulai dengan memperbaiki kinerja tenaga pendidiknya atau dalam hal ini guru. Selain itu, tenaga pendidik 
juga harus lebih mengeksplorasi teknik-teknik terbaik yang akan diajarkan kepada siswa dan disesuaikan dengan passion yang dimiliki oleh siswa tersebut. Tanamkan pula dalam benak siswa bahwa "Selama terdapat cara-cara sederhana, mengapa harus memakai cara yang rumit?" Sebab, selama ini kecenderungan siswa menjadi lebih cepat jenuh dalam menghadapi pembelajaran matematika disebabkan karena pembelajarannya yang terlalu terpaku kepada aturan yang notabene rumit, padahal apabila siswa mengetahui cara yang lebih mudah, siswa pun pasti akan mampu mengerjakannya dengan senang hati.

Untuk unsur budaya yang cocok disisipkan pada pembelajaran matematika, sejauh ini responden memberikan tanggapan yang beragam. Diantaranya yaitu dengan memasukkan unsur budaya tradisional setempat yang dapat digunakan sebagai media pembelajaran matematika, memasukkan unsur lagu dan kesenian daerah, serta memasukkan budaya masyarakat pada umumnya yang diambil dari kehidupan sehari-hari seperti menabung dan jual beli.

Dalam hal demikian, penulis lebih condong menggunakan budaya yang berorientasi kepada lagu dan kesenian daerah untuk digunakan secara umum pada pembelajaran matematika. Selain lagu daerah yang berada di Indonesia sangat banyak dan bervariasi, juga tangga nada yang dihasilkan dari setiap lagu itu dapat berbeda-beda. Tangga nada memuat angka sederhana, maka tidak menutup kemungkinan susunan angka tersebut dapat dialihfungsikan sebagai perantara pembelajaran matematika di sekolah.

Misalnya ketika guru menyisipkan lagu Bubuy Bulan, maka tangga nada yang

Copyright (02019, Jurnal Didactical Mathematics p-ISSN: 2622-7525, e-ISSN: 2654-9417 dibuat cenderung kepada tangga nada diatonis. Diatonis sendiri menggunakan urutan nada Do-Re-MiFa-Sol-La-Si atau dapat diurutkan sebagai angka 1-2-3-4-5-6-7. Untuk pemahaman sederhananya, dalam satu kalimat terdapat beberapa bilangan, diantaranya:

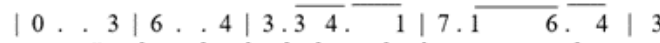
Bu buy bu lan bubuy bu lan sangrai ben tang

Maka, dalam hal ini guru dapat memberikan pemahaman kepada siswanya bahwa dalam satu kalimat yang diperoleh dari tangga nada tersebut di atas, terdapat beberapa bilangan yang dapat disebut dengan bilangan cacah. Bilangan cacah sendiri merupakan bilangan yang terdiri dari angka-angka positif atau bilangan asli yang dimulai dari angka 0 (nol), 1 (satu), 2 (dua) dan seterusnya. Sedangkan untuk bilangan asli sendiri, memiliki garis pengertian yang serupa dengan bilangan cacah, namun untuk bilangan asli, angka pembilangnya dimulai dari angka 1 (satu), 2 (dua), 3 (tiga) dan seterusnya (Wahyu, 2014)

\section{KESIMPULAN}

Dari hasil analisis pada pembahasan dapat disimpulkan:

1. Untuk pendidikan matematika yang diberikan di sekolah sejauh ini dapat dikatakan lebih baik dari sebelumnya, banyak pula variasi tambahan dalam materi yang diberikan dari buku ajar. Namun, sebagian besar siswa masih memiliki kecenderungan kurang menyukai pembelajaran matematika. Sebab, metode pembelajaran yang diajarkan masih kurang memacu siswa untuk menyukai matematika. Juga, pembelajaran matematika yang diajarkan oleh guru di sekolah 
dinilai terlalu monoton dan membosankan.

2. Kesulitan umum siswa terhadap pembelajaran matematika saat ini terletak pada rumus-rumus matematika yang dinilai cukup rumit, serta penanganan siswa yang malah membangun stigma negatif mengenai pembelajaran matematika.

3. Untuk membangun daya minat siswa dalam mempelajari matematika, guru sebagai tenaga pendidik perlu lebih mengeksplorasi skema pembelajaran yang menyenangkan dan tidak terlalu terpatok pada buku ajar. Misalnya dengan memasukkan unsur nonformal, dalam hal ini budaya, dengan pembelajaran matematika.

4. Memasukkan unsur budaya dengan pembelajaran matematika patut dipertimbangkan lebih lanjut untuk diuji coba. Sebab, dalam skema pembelajaran matematika berbasis budaya, dapat memungkinkan siswa untuk lebih mengeksplorasi daya kreativitas serta aktivitas siswa itu sendiri melalui pengaplikasian dari matematika melalui unsur budaya. Namun, untuk lebih lanjutnya belum dapat sepenuhnya menyimpulkan apakah skema pembelajaran tersebut dapat efektif atau tidak.

5. Unsur budaya yang dapat dimasukkan kedalam pembelajaran matematika formal salah satunya yaitu, guru dapat memasukkan unsur lagu dan kesenian daerah sebagai media pembelajaran matematika. Seperti mengetahui tangga nada yang dapat disandingkan dengan pertanyaan mengenai bilangan cacah.

\section{Saran}

Mengacu pada hasil temuan dan pembahasan karya tulis di atas, penulis menemukan bahwa kesulitan siswa secara umum hingga saat ini yaitu menganggap bahwa pembelajaran matematika di sekolah dinilai terlalu monoton bahkan cenderung membosankan. Maka dari itu, penulis menyarankan akan lebih baik jika skema pembelajaran di sekolah terlebih dibenahi, dengan cara-cara yang lebih menyenangkan. Contohnya yaitu menerapkan pembelajaran matematika yang disatukan dengan unsur budaya.

\section{REFERENSI}

Bishop, J.A.(1991). The Simbolic Technology Calet Mathematics its Role in Education. Bullatin De La Societe Mathematique, De Belgique, T,XLIII

Bishop, J.A.(1994b). Cultural Conplicts in the Mathematics Education of Indigenous people. Clyton, Viktoria: Monash University.

Mata Pelajaran: KBBI V, 2016. diambil pada tanggal 29 April 2019.

Mulyana, Rahmat. 2004. Mengartikan Pendidikan Nilai. Bandung: Alfabeta.

Pixten, R.(1994). Ethnomatics, and its Praktice. For the Learning of Mathematics, 14(2), Halaman 2325.

Supriadi. 2010. Pembelajaran Etnomatematika dengan Media Lidi dalam Operasi Perkalian Matematika untuk Meningkatkan Karakter Kreatif dan Cinta Budaya Lokal Mahasiswa PGSD. Jurnal Seminar Nasional STKIP 
Siliwangi. Serang: Sekolah Pascasarjana UPI.

Wahyu Purnomo, Yoppy. 2014.

Bilangan Cacah dan Bulat.

Sebuah Tinjauan Konsep dan

Instruksional dalam

Pembelajaran. Bandung: Alfabeta. 